\title{
A comparative evaluation of regional subsidies for collaborative and individual R\&D in small and medium-sized enterprises
}

\author{
Annalisa Caloffi ${ }^{\mathrm{a}, \mathrm{e}, *}$, Marco Mariani $^{\mathrm{b}}$, Federica Rossi ${ }^{\mathrm{c}, \mathrm{e}}$, Margherita Russo $^{\mathrm{d}, \mathrm{e}}$ \\ a Department of Economics and Management, University of Florence, Italy \\ ${ }^{\mathrm{b}}$ Regional Institute for Economic Planning of Tuscany, IRPET, Italy \\ ${ }^{\mathrm{c}}$ School of Business, Economics and Informatics, Birkbeck, University of London, United Kingdom \\ ${ }^{\mathrm{d}}$ Department of Economics, University of Modena and Reggio Emilia, Italy \\ e Centre for the Analysis of Public Policies - CAPP, University of Modena and Reggio Emilia, Italy
}

\section{A R T I C L E I N F O}

\section{JEL classification:}

O38

$\mathrm{O} 32$

D04

Keywords:

Public subsidies

SMEs

Collaborative R\&D projects

Individual R\&D projects

Programme evaluation

\begin{abstract}
A B S T R A C T
We analyse whether public subsidies supporting collaborative research and development (R\&D) projects in small and medium-sized enterprises (SMEs) are able to encourage persistent R\&D investment and interorganisational networking more than subsidies supporting individual R\&D projects. Adopting a counterfactual approach to policy evaluation, we compare subsidies for collaborative R\&D and for individual R\&D implemented in the same Italian region in the same period. Our findings suggest that, once public support is no longer available, the two subsidies have different effects on different types of SMEs. If the policymakers' objective is to increase the number of R\&D-performing SMEs over time, they should provide subsidies for collaborative R\&D to firms with modest $R \& D$ experience. If their objective is to increase the amount of spontaneous R\&D investment over time, they should target SMEs with some prior R\&D experience, using either subsidy. Finally, if their objective is to induce SMEs to network with external organisations, subsidies for collaborative R\&D projects should be preferred to subsidies for individual R\&D projects.
\end{abstract}

\section{Introduction}

Innovation policies often target small and medium-sized enterprises (SMEs), many of which lack adequate financial or human resources to undertake research and development (R\&D) activities (Vossen, 1998; Peneder, 2008; Ortega-Argilés et al., 2009). In countries with multilevel policy frameworks, such policies are more likely to be implemented at the regional level (Blanes and Busom, 2004), where interventions often pursue local development objectives. As a consequence, many regional innovation policies aim not only to support the R\&D efforts of the most dynamic SMEs, but also to expand the range of SMEs that perform some amount of R\&D. This dual objective is typical of lagging economies as well as of more advanced ones: even in the latter, in fact, many SMEs do not innovate at all and, among those that do, many engage in forms of innovation that are not necessarily based on R\&D (Som 2012).

Policymakers can pursue the dual objective to support dynamic SMEs' R\&D efforts and encourage more SMEs to take up R\&D activities through different policy instruments, including subsidies, tax-credits, loans or consultancies. We focus on subsidies and, in particular, on two distinct approaches to delivering them. On the one hand, policymakers can provide SMEs with subsidies for individual R\&D projects, in order to overcome the financial hurdles that prevent them from engaging in $\mathrm{R}$ $\& D$ activities or limit the amount of their R\&D investment. Until recently, this is by far the most common approach. On the other hand, policymakers can grant subsidies to SMEs that perform collaborative $\mathrm{R}$ $\& D$ projects with external organisations (such as universities, public bodies, other firms or others), a more complex form of support that mixes financial and behavioural incentives. Besides providing financial support, these policies stimulate SMEs to internalise spillovers, pool resources and share costs (Hagedoorn et al., 2000). By encouraging collaboration, policymakers aim to address network failures that can occur whenever firms' lack of linkages with other organisations leads to an insufficient development of complementarities, learning processes, and creation of new ideas, or when firms are trapped in relational and knowledge lock-ins (Carlsson and Jacobsson, 1997; Hagedoorn et al., 2000; Hekkert and Negro, 2009). This can be particularly important for SMEs, which are often constrained by limited internal resources (Nooteboom, 1994).

R\&D collaboration policies have gained popularity in recent years (Metcalfe and Georghiou, 1997; Rahm et al., 2000). However, despite their growing international diffusion, there is still little empirical

\footnotetext{
* Corresponding author at: Department of Economics and Management, University of Florence, via delle Pandette, 32, 50127 Florence, Italy.

E-mail addresses: annalisa.caloffi@unipd.it (A. Caloffi), marco.mariani@irpet.it (M. Mariani), f.rossi@bbk.ac.uk (F. Rossi), margherita.russo@unimore.it (M. Russo).
} 
evidence regarding their ability to support R\&D and networking both in absolute terms and compared with other more established approaches, such as subsidies to individual R\&D.

Several recent studies comparing the effects of different R\&D policies have either contrasted policies implemented at different government levels (Marzucchi and Montresor, 2015; Huergo and Moreno, 2017), or compared R\&D subsidies and R\&D tax-credits (Hægeland and Møen, 2007; Busom et al., 2014; Garza et al., 2015). To the best of our knowledge, a comparative evaluation of subsidies for individual and collaborative R\&D projects has not yet been performed.

Focusing on SME innovation policy, our contribution aims to address this gap and to stimulate further debate on the topic. In particular, we analyse whether subsidies for SMEs to perform collaborative R\&D projects are more or less able than subsidies for SMEs' individual R\&D projects to stimulate R\&D and networking effects after the subsidised project is completed. The term ' $R \& D$ effects' refers to the increase in $R \&$ D investment induced by the receipt of public aid (David and Hall, 2000). From a social viewpoint, this can be achieved both through an increase in R\&D investment by all firms, including those that were already $R \& D$ performers, and through an increase in the number of R\&D performers (González et al., 2005; Arqué-Castells and Mohnen, 2015; Garza et al., 2015). In what follows we will consider both aspects. The network effects - which is part of the broader notion of behavioural additionality (Buisseret et al., 1995; Autio et al., 2008) - refers to the increase in collaborations with external organisations induced by the receipt of public aid (Georghiou and Clarysse, 2006; Falk, 2007; Busom and Fernández-Ribas, 2008).

A striking result emerging from the previous literature is that individual R\&D subsidies can support networking (Busom and FernándezRibas, 2008; Antonioli et al., 2014). Therefore, one might wonder whether subsidies for collaborative R\&D are really needed to boost firms' networking propensity, or whether individual R\&D subsidies may be sufficient for this purpose. Our study can potentially contribute to improving policy design besides advancing general knowledge of comparative policy effects.

The paper is organised as follows. In Section 2 we put forward an interpretative framework to guide us in the analysis of the comparative effects of the two policies. Section 3 describes in some detail the empirical object of the analysis: two different policy interventions - one being a subsidy for collaborative R\&D projects and the other a subsidy for individual R\&D projects. Both interventions were implemented in the same region (Tuscany, Italy), in the same programming period (2000-2006), by the same public authority (the regional government), and targeted the same types of beneficiaries (SMEs). Section 4 presents data and variables, and Section 5 explains our empirical strategy, which uses a matching approach applied to the case of multiple treatments, as proposed by Lechner (2002a, 2002b). So far, this approach has not been adopted in relation to enterprise and innovation policies. Sections 6 and 7 present and discuss the results. Finally, Section 8 concludes with policy implications and proposed avenues for further research.

\section{Interpretative framework and resulting hypotheses}

It has been argued that $R \& D$ subsidies can increase aggregate $R \& D$ in two (non mutually exclusive) ways: they can increase the number of firms performing R\&D (extensive margin) or the R\&D investment made by any firm (intensive margin) (González et al., 2005; Arqué-Castells and Mohnen, 2015; Garza et al., 2015). Arqué-Castells and Mohnen (2015) suggest that R\&D subsidies can stimulate the increase in R\&D over one or the other margin depending on their size. Subsidies that are large enough to cover the cost of initiating R\&D activities (i.e. the entry threshold, which is rather high due to the presence of sunk costs) can affect the extensive margin, while subsidies above the continuation threshold - which is lower than the entry threshold - can affect the intensive margin.
Other contributions suggest that different types of policy instruments have different effects on R\&D increases over the intensive or the extensive margin. Comparisons between R\&D tax-credits and individual subsidies (Busom et al., 2014; Garza et al., 2015) find that, because of their greater simplicity and flexibility, tax-credits are better able to increase R\&D investment on the part of R\&D-performing firms that do not suffer from serious financing constraints and, therefore, would not need to receive the aid in advance. Instead, subsidies are more attractive for financially-constrained firms such as SMEs and suited to encourage both R\&D entry and higher R\&D investment.

What type of subsidy - to individual or collaborative R\&D projects works better remains an open question, especially if we are interested in assessing the effectiveness of such subsidies with respect to their legacy effects (Roper and Hewitt-Dundas, 2014). In our study, we investigate the effects of the programmes on firms' later R\&D behaviour, in a time where public aid is no longer available. At this time, the main effect that can be investigated is R\&D persistence: the extent to which firms that received the subsidy continue to perform R\&D. In this context, the definition of extensive and intensive margin put forward by the previous literature needs to be adjusted: one might view persistence effects as a matter of higher probability of performing R\&D (extensive margin), or as a matter of higher R\&D investment (intensive margin) during the unsubsidised follow-up period. As we will explain in what follows, this distinction is relevant because we argue that the two policies we focus on can have different effects on the different margins.

There are a number of reasons for focusing on R\&D persistence, particularly when analysing SMEs. It is known that SMEs tend to carry out, if any, informal R\&D activities (Kleinknecht and Reijnen, 1991), often in an intermittent and semi-structured way (Rammer et al., 2009). This approach limits the accumulation of internal R\&D skills over time, increasing SMEs' dependence on the inflows of external knowledge and know-how, which are subject to search, screening and other transaction costs (Fontana et al., 2006), and may ultimately result in discontinuous R\&D practice (Rammer et al., 2009). The presence of persistence effects suggests that a policy has been able to encourage SMEs to engage in R\& D more continuously, independently from future subsidisation programmes. As argued by Klette and Møen (2012), positive effects may be expected to arise after a time lag has passed due to the fact that the implementation of the subsidised project can induce learning-by-doing in R\&D activities, and thus change the firms' future profit opportunities in favour of more R\&D-intensive products.

\subsection{Effects on $R \& D$}

Both in the case of policies supporting collaborative R\&D projects and of those supporting individual R\&D projects, the subsidy may help SMEs carry out $R \& D$ activities and learn from the project. Thanks to experiential learning processes, employees and managers can develop new or improved skills and increase their capacity to interpret different aspects of the creative process, which can drive change in company routines (Cyert and March, 1963; Clarysse et al., 2009). Moreover, during the project's development, the firm can build or acquire some innovation infrastructures or equipment, which can be used in future innovation projects. Once the subsidised project is over, new and improved knowledge, skills, capabilities, routines, and, possibly, equipment and infrastructures, improve the value of the firm's future innovation projects and therefore can increase the probability that it will continue to invest in R\&D with its own funds (Clarysse et al., 2009; Roper and Hewitt-Dundas, 2014). The increase in absorptive capacity that results from new and improved skills can strengthen this effect (Cohen and Levinthal, 1989). As investing in R\&D has become less costly, the SME can even decide to increase the amount invested. However, the effect on the amount invested is more uncertain because, for example, there could be an "optimal" project dimension that the SME, even for organizational or cognitive reasons, can manage (Bocci and Mariani, 2015). 
R\&D collaboration subsidies combine financial and behavioural incentives, since they are designed to trigger interorganisational learning. ${ }^{1}$ An important prerequisite for triggering interorganisational learning processes is that the firm has internal skills, capabilities, routines and governance systems that allow or facilitate collaborative work with external organisations (Dyer and Singh, 1998), which is not always the case in SMEs (Nooteboom, 1994; Van Gils and Zwart, 2004; Teirlinck and Spithoven, 2013). These knowledge and skills are difficult to learn, because their partly uncodified nature can hamper their diffusion to third parties (Polanyi, 1966; Howells, 1996; Kale et al., 2000). The collaborative work that develops during the subsidised project can instead facilitate such diffusion, as far as it facilitates the development of interorganisational trust (Dodgson, 1992, 1993). Public funding can support either the experimentation with brand-new collaborative practices or the fine-tuning of existing ones, which can be used in future activities. After the end of the subsidised project, the firm will find it more useful and less costly to collaborate with external organisations. This is particularly important in environments where collaboration is crucial for competitiveness (Baldwin and Clark, 2000; Chesbrough et al., 2006), and particularly for SMEs, which can rely on relatively scarce internal resources and competencies (Narula, 2004; Laursen and Salter, 2006; Lee et al., 2010). An SME that has learned how to collaborate with external partners knows how to access and manage the different pieces of knowledge and skills that are needed to carry out an R\&D project (Van de Vrande et al., 2009) and therefore will be more likely to continue to perform R\&D activities.

This effect can be strengthened by the fact that the collaborative work that takes place during the funded project can facilitate the sharing of other knowledge and skills that would otherwise be difficult to transmit and absorb such as, for example, partners' strategies or expectations (e.g. with respect to the development of a certain sector or a certain technology), or information about the capabilities and reliability of customers, suppliers or other organizations that play an important role in a certain sector or technology (Powell, 1996). Although this knowledge and information are not of primary importance for R\&D, they can facilitate the development of such activities in SMEs, which have a relatively small human capital pool, few managers and little resources to be invested in searching and screening of the external context (Vossen, 1998).

Therefore, we put forward the following hypothesis concerning persistent $R \& D$ effects along the extensive margin:

H1. The probability to continue to invest in $R \& D$ is higher for firms receiving subsidies for a collaborative $R \& D$ project than for firms receiving subsidies for an individual $R \& D$ project

If - as we believe - there is higher probability of R\&D persistence due to the subsidy, we may conclude that, from an aggregate perspective, the programme has succeeded in extending the pool of SMEs that perform R\&D without public subsidy (extensive margin). Given that identifying and finding external partners and managing R\&D activities may have become less costly, SMEs may decide to invest increasing amounts in R\&D. However, as stated above, this effect is rather uncertain as SMEs could continue to manage R\&D projects of relatively small size (Bocci and Mariani, 2015). Therefore, we do not state a hypothesis concerning persistent R\&D effects along the intensive margin.

\subsection{Effects on networking}

Based on the previous arguments, SMEs that have participated in the policy supporting collaborative R\&D should be more likely to continue to collaborate in the future with external organizations than

\footnotetext{
${ }^{1}$ Obviously, nothing prevents a firm that receives a subsidy for individual R\&D from using the subsidy to purchase external knowledge, if the firm is aware of such need. However, this type of policy requires that most of the activity is carried out within the boundaries of the firm.
}

SMEs that have participated in the policy subsidising individual R\&D projects. For this reason, we put forward the following hypothesis concerning persistent network effects:

H2. Ex-post networking effects are higher for firms receiving subsidies for a collaborative $R \& D$ project than for firms receiving an individual $R \& D$ subsidy

In particular, networking effects may differ according to different types of partners. SMEs are known to find it particularly difficult to initiate interactions with universities and public research organisations (Mohnen and Hoareau, 2003; Arundel and Geuna, 2004; Laursen and Salter, 2004), due to their large cognitive and organisational distance. SMEs and public research organisations in fact are characterised by different cultures and languages (Bruneel et al., 2010; Lockett and Wright, 2005; Sauermann and Stephan, 2013; Russo and Rossi, 2009), approaches to innovation (Barnes et al., 2002), and research orientation (Petruzzelli and Rotolo, 2015). Moreover, SMEs often possess few spare resources in order to attempt to overcome these obstacles. Therefore, collaborative R\&D subsidies may be particularly helpful in order to encourage SMEs to interact with universities, rather than with other types of firms with whom SMEs might interact more easily even in the absence of subsidies.

Once again, we refer to the probability of adopting a certain behaviour (in this case, a networking behaviour) and not to a purely additional effect. Indeed, the latter would require SMEs to increase the number of external organisations they collaborate with, while we do not posit that SMEs will always expand their network. At the same time, SMEs will not necessarily continue to collaborate with the same organizations they previously collaborated with (Caloffi et al., 2017). The fact of having experienced collaborative work and having adapted their internal routines to collaboration makes collaboration easier for the SMEs that participated in R\&D collaboration policies than those who participated in the other policy under analysis.

To test the hypotheses $\mathrm{H} 1$ and $\mathrm{H} 2$ it would be insufficient to estimate the effects of the two policies with respect to a counterfactual, nopolicy situation and compare them. To estimate the differential effect of one policy versus the other, we need to account for the fact that firms that decide to participate in one type of policy programme are not necessarily the same that decide to participate in the other type of programme. Our empirical strategy will be described in Section 5.

\section{Tuscany's regional policy in support of R\&D}

Our empirical analysis focuses on two distinct R\&D policy interventions targeting SMEs that were implemented in an Italian region (Tuscany) in the programming period 2000-2006 (2002-2008 is the actual period of implementation) using European Regional Development Funds. Since the constitutional reform of 2001, Italian regions were conferred a number of competencies related to enterprise and innovation policy, based on the idea that peripheral governments should respond to local needs better than the central government (Caloffi and Mariani, 2018).

Similarly to several other Italian regions, Tuscany is characterised by a relatively low aggregate level of private R\&D investment and a very high share of SMEs, mostly belonging to low and medium-tech sectors (Hollanders and Es-Sadki, 2017). However, unlike other Italian regions, Tuscany has adopted a dual approach to SME innovation policy from the outset. It implemented both classical subsidies to individual $\mathrm{R}$ $\& D$ projects, as well as subsidies for collaborative R\&D projects, the latter inspired by the Regional Innovation System framework which has gained popularity since the late 1990s (Cooke et al., 1997; Russo and Rossi, 2009). Both policies were designed and implemented by the same policymaker, in the same time frame and with the same funds, and aimed to support relatively small R\&D projects carried out by SMEs. The similarity between the ultimate objectives of the two programmes was apparent from the official programming documents and calls for 
applications, and was confirmed by the policymakers we interviewed. ${ }^{2}$ Both programmes resorted to the same instrument: an R\&D subsidy delivered under the de minimis clause. ${ }^{3}$ However, one policy provided subsidies for individual firms to perform their own R\&D projects, while the other subsidised projects carried out by temporary consortia or associations between SMEs and other organisations, such as universities, research centres, or innovation intermediaries (Howells, 2006; Russo and Rossi, 2009). The latter intervention was premised on the assumption that the inclusion of these supposedly more knowledgeable organisations would mainly benefit participating SMEs. Therefore, it makes sense to evaluate the impact of the policy on SMEs, rather than on the other participants. Almost all the participants in the R\&D collaboration policy were regional organisations. Extra-regional organisations could join the projects, but without receiving any subsidy.

In both policies under analysis, public funding took the form of a non-repayable subsidy, which was granted conditional on the positive evaluation, by a committee of field experts, of the innovative projects presented by firms in response to public tenders. The final admission decision was based solely on project quality. The quality requirements set by the regional government were related to the degree of novelty of the project, the technical ability of the firm (or the consortium) to carry it out, the market potential and the potential spillovers of the project.

Both policies had very broad sector and technology targets, which ranged from the traditional "made in Italy" (e.g.: textiles, jewellery) to high-tech manufacturing, and included also selected types of services.

As both policies admitted multiple participations (either over time i.e. to different calls for funding opened over the years - or, for the collaborative R\&D subsidies, in multiple concurrent partnerships), we restrict our analysis to SMEs receiving a subsidy only once. As the effects of multiple subsidies could be additive, this choice is motivated by the wish to keep things as clear as possible. The implication of this choice is that inference will be valid for firms - the overwhelming majority in both programmes - receiving only one subsidy. We also excluded from the analysis those firms that received the subsidy from 2006 onwards, as the investment outcomes of such firms might have been later affected by the economic crisis. Hence, we start from a set of 292 SMEs that received only one subsidy for a collaborative R\&D project, and from a set of 120 firms that received only one subsidy for an individual R\&D project.

\section{Data and outcome variables}

The data for our study refer not only to the two sets of firms that participated in the two policy programmes under investigation, but also to a third, and wider, set of firms that did not participate in either of the two programmes. The inclusion in the analysis of this latter set of firms will be motivated in Section 5 .

For each of these three sets of firms, we collected the relevant data using administrative sources and surveys. Time-varying data refer to two different time points. In particular, information on the firms' background characteristics refers to one year before the start of the subsidised project, whereas information on the outcomes of interest refers to 2 years after the completion of the subsidised project. As the

\footnotetext{
${ }^{2}$ The first interviews to policymakers were made in 2001 and other meetings followed during and after the implementation of the two programmes, also to acquire data on the participating firms. Over time, we have interviewed face-to-face the whole staff that managed the programmes (5 public officers and their director), asking them information about the objectives that the regional government wanted to pursue with these programmes, their implementation process as well as on the broader policy framework in which these programmes were inserted.

${ }^{3}$ The "de minimis" rule, first set by the European Commission in 1992, is designed to benefit small and medium sized enterprises (SMEs). At the time of the policies investigated in this paper, the rule provided that subsidies of less than $€ 100,000$ granted to a firm over a period of 3 years did not constitute "State Aid" within the meaning of the EC Treaty's ban on aid liable to distort competition (Article 87). The cumulation of such small subsidies was possible up to the ceiling of $€ 200,000$.
}

duration of projects under both programmes was about 1 year, the time distance between treatment and outcome was approximately 3 years.

Based on the discussion presented in Section 3 and on the hypotheses therein, in order to measure the effects of the policies we chose to focus on the following five outcome variables, all measured after the completion of the subsidised project: (1) a binary variable called $R \& D$ equal to one if the firm performs internal R\&D, and zero otherwise; (2) a continuous variable with the amount of the firm's $R \& D$ investment ${ }^{4}$; (3) a binary variable called Collaborations equal to one if the firm was involved in R\&D collaboration with external organisations (either universities or other firms), and zero otherwise; a couple of variables detailing the type of partners in R\&D collaboration, and, in particular (4) a binary variable called Universities equal to one if the firm was involved in $R \& D$ collaboration with universities or other research organisations, and zero otherwise; (5) a binary variable called Other Firms equal to one if the firm was involved in R\&D collaboration with other firms, and zero otherwise.

The outcome variables of interest had to be collected through an ad hoc survey since they are mostly unavailable in balance-sheet data. ${ }^{5}$ The survey also offered the opportunity to collect information on the outcome variables prior to the programme. Information on time-invariant characteristics, such as legal form, sector and province, as well as on the number of employees prior to the programme, was drawn from the Statistical Archive of Active Enterprises (ASIA), maintained by the Italian Institute of Statistics (ISTAT).

Whereas the list of subsidised firms was provided by the regional government implementing the two programmes, completely untreated firms belonging to eligible sectors were hundreds of thousands in the region, far too many to be all surveyed. In order to identify a manageable set of untreated firms that could be used as controls, we adopted a matched sampling approach (Rosenbaum and Rubin, 1985). This strategy is based on the estimation of a preliminary propensity score, one for each programme, from a number of basic background characteristics available on the full population of eligible regional enterprises, such as those available in the ASIA archive mentioned earlier (number of employees, legal form, sector and province). Based on these preliminary propensity scores, we selected a pool of untreated firms by matching each beneficiary to its five nearest neighbours, without replacement.

We then launched the telephone survey to all beneficiary firms and to their matched potential controls. The questionnaire was submitted in 2010 to the 120 firms that received only one subsidy for individual R\&D projects and to their potential controls, and in 2014 to the 292 firms that received only one subsidy for collaborative R\&D projects prior to 2006 and to their potential controls. The interviews were with the entrepreneur or a manager who had been involved in the subsidised R\& D projects (for treated firms) or who was responsible for R\&D activities. Only 189 beneficiary SMEs responded: all 120 firms that received the subsidy to individual R\&D, and 69 firms that received the subsidy to collaborative R\&D. ${ }^{6}$ However, the subset of respondents is rather similar, in a range of basic background characteristics, to the two full populations of beneficiary firms, which suggests that the response rate is uncorrelated with such observables and that there could be more individual reasons for non-response (Bloom and Van Reenen, 2010). ${ }^{7}$

\footnotetext{
${ }^{4}$ The values of R\&D investment are expressed at constant prices, base year is 2001 . To this end we employed the R\&D investment deflator provided by the Italian National Institute of Statistics.

${ }^{5}$ The value of R\&D investment collected through the interview was later cross-checked in balance sheets.

${ }^{6}$ All contacted firms received a written invitation to respond by the regional government. In the survey aimed at SMEs that received the subsidy for individual R\&D projects and their potential controls, we could also rely on the crucial support of local business associations. Unfortunately, the support of business associations was not available when we later surveyed SMEs that received the subsidy for collaborative R\&D projects, which explains the much lower response rate achieved with these firms.

7 Descriptive statistics on the main background characteristics of responding and nonresponding firms are available upon request to the authors.
} 
Table 1

Means of the background and outcome variables for firms that received the subsidy for collaborative R\&D projects and for firms that received the subsidy for individual R\&D projects and their untreated controls.

\begin{tabular}{|c|c|c|c|c|}
\hline \multirow[t]{2}{*}{ Variable } & \multicolumn{2}{|c|}{$\begin{array}{l}\text { Subsidies for collaborative } \\
\text { projects }\end{array}$} & \multicolumn{2}{|c|}{$\begin{array}{l}\text { Subsidies for individual } \\
\text { projects }\end{array}$} \\
\hline & Treated & Controls & Treated & Controls \\
\hline $\mathrm{R} \& \mathrm{D}_{-1}(1 / 0)$ & 0.580 & 0.353 & 0.833 & 0.430 \\
\hline $\mathrm{R} \& \mathrm{D}$ investment ${ }_{-1}$ & 164.021 & 77.271 & 179.823 & 47.340 \\
\hline Universities $_{-1}(1 / 0)$ & 0.362 & 0.142 & 0.183 & 0.076 \\
\hline Other firms ${ }_{-1}(1 / 0)$ & 0.391 & 0.310 & 0.192 & 0.107 \\
\hline Sector: food & 0.072 & 0.059 & 0.017 & 0.006 \\
\hline Sector: marble products & 0.058 & 0.090 & 0.033 & 0.032 \\
\hline $\begin{array}{l}\text { Sector: textiles, clothing, } \\
\text { shoes }\end{array}$ & 0.145 & 0.130 & 0.367 & 0.340 \\
\hline Sector: chemicals & 0.043 & 0.031 & 0.033 & 0.027 \\
\hline $\begin{array}{l}\text { Sector: machinery and } \\
\text { equipment }\end{array}$ & 0.145 & 0.146 & 0.167 & 0.221 \\
\hline $\begin{array}{l}\text { Sector: electrical } \\
\text { machineries and } \\
\text { electronics }\end{array}$ & 0.087 & 0.071 & 0.092 & 0.077 \\
\hline Sector: automotive & 0.058 & 0.015 & 0.025 & 0.027 \\
\hline Sector: furniture & 0.043 & 0.074 & 0.058 & 0.066 \\
\hline $\begin{array}{c}\text { Sector: electricity, gas, } \\
\text { water distribution }\end{array}$ & 0.014 & 0.012 & 0.008 & 0.002 \\
\hline Sector: construction & 0.058 & 0.037 & 0.017 & 0.008 \\
\hline $\begin{array}{l}\text { Sector: wholesale and } \\
\text { retail trade }\end{array}$ & 0.014 & 0.056 & 0.025 & 0.030 \\
\hline Sector: ICT & 0.087 & 0.093 & 0.033 & 0.057 \\
\hline Sector: R\&D & 0.043 & 0.012 & 0.008 & 0.014 \\
\hline Sector: business services & 0.072 & 0.118 & 0.033 & 0.039 \\
\hline Sector: other sectors & 0.058 & 0.056 & 0.083 & 0.054 \\
\hline Employees_- $_{-1}$ up to 9 & 0.464 & 0.452 & 0.158 & 0.393 \\
\hline Employees $_{-1}: 10-29$ & 0.319 & 0.313 & 0.408 & 0.387 \\
\hline Employees $_{-1}:$ 30-49 & 0.101 & 0.167 & 0.367 & 0.188 \\
\hline Employees-1: $50+$ & 0.116 & 0.068 & 0.067 & 0.032 \\
\hline $\begin{array}{l}\text { Public or private limited } \\
\text { company }(1 / 0)\end{array}$ & 0.667 & 0.328 & 0.983 & 0.987 \\
\hline Province: Massa Carrara & 0.087 & 0.053 & 0.033 & 0.030 \\
\hline Province: Lucca & 0.043 & 0.074 & 0.067 & 0.079 \\
\hline Province: Pistoia & 0.029 & 0.043 & 0.100 & 0.077 \\
\hline Province: Florence & 0.246 & 0.257 & 0.325 & 0.258 \\
\hline Province: Livorno & 0.087 & 0.080 & 0.008 & 0.022 \\
\hline Province: Pisa & 0.101 & 0.183 & 0.117 & 0.128 \\
\hline Province: Arezzo & 0.029 & 0.062 & 0.058 & 0.114 \\
\hline Province: Siena & 0.130 & 0.115 & 0.042 & 0.082 \\
\hline Province: Grosseto & 0.058 & 0.034 & 0.008 & 0.016 \\
\hline Province: Prato & 0.188 & 0.099 & 0.242 & 0.194 \\
\hline \multicolumn{5}{|l|}{ OUTCOMES } \\
\hline $\mathrm{R} \& \mathrm{D}(1 / 0)$ & 0.652 & 0.378 & 0.817 & 0.448 \\
\hline $\mathrm{R} \& \mathrm{D}$ investment & 161.946 & 43.757 & 179.977 & 53.379 \\
\hline Collaborations $(1 / 0)$ & 0.580 & 0.220 & 0.358 & 0.154 \\
\hline Universities $(1 / 0)$ & 0.464 & 0.118 & 0.242 & 0.081 \\
\hline Other firms $(1 / 0)$ & 0.391 & 0.186 & 0.250 & 0.119 \\
\hline N. of observations & 69 & 323 & 120 & 630 \\
\hline
\end{tabular}

Note to table: R\&D investment figures are expressed at constant prices, with base year 2001, computed using the R\&D investment deflator provided by the Italian National Institute of Statistics.

All background variables (henceforth also covariates) are listed in Table 1, along with their means in the two sets of firms that received the collaborative or the individual R\&D subsidy, and in the two sets of related (untreated) controls.

From Table 1, we see that firms under the two programmes had partially different background characteristics before they received the subsidies. In fact, firms that went on to receive the subsidy to collaborative $R \& D$ projects were already more likely to have relationships with external partners. ${ }^{8}$ On the other hand, firms that went on to receive the subsidy to individual R\&D projects had already a higher propensity to engage in internal R\&D. ${ }^{9}$

\section{Empirical strategy}

We view our estimation problem in the light of the potential-outcomes framework (Imbens and Rubin, 2015). For each firm $i$ there are three potential outcomes for each outcome variable $Y$ : the value of $Y$ if the firm receives a subsidy for a collaborative R\&D project, $Y_{i}(c)$; the value of $Y$ if the firm receives a subsidy for an individual R\&D project, $Y_{i}(s)$; and the value of $Y$ if the firm does not receive a subsidy at all, $Y_{i}(u)$. For each firm $i$, the effect of the subsidy for a collaborative project relative to a no-subsidy situation can be defined as the difference between the firm's two potential outcomes, $Y_{i}(c)-Y_{i}(u)$, whereas the effect of the subsidy for a collaborative project relative to a subsidy for an individual project can be defined as the difference between the firm's two potential outcomes, $Y_{i}(c)-Y_{i}(s)$, and so forth for each pair of the possible treatment levels $T_{i}=(c, s, u)$. Unfortunately, only the potential outcome associated with the treatment actually received is observable, whereas the two counterfactual potential outcomes are not. Therefore, attention shifts to estimable average quantities and to the contrast between these quantities. Outside of experiments, the comparison between the average $Y$ relative to groups of units receiving different treatments returns causal effects provided that some untestable assumptions are made. Given the data at hand, we choose to invoke the assumption of strong ignorability, which was extended to the multiple-treatment case by Lechner (2002a, 2002b) and consists of two components:

(i) Unconfoundedness: $Y_{i}(u), Y_{i}(c), Y_{i}(s) \perp T_{i} \mid \boldsymbol{X}_{i}$, where $\boldsymbol{X}_{i}$ is a vector of pre-treatment covariates observed for each firm $i$, i.e. treatment assignment is independent of the potential outcomes conditional on the observed pre-treatment covariates;

(ii) Overlap: $0<\operatorname{Pr}\left(T_{i}=t \mid \boldsymbol{X}_{i}=\boldsymbol{x}\right)<1$, i.e. the treatment status is not a deterministic function of the covariates and, therefore, there is room for ceteris paribus comparisons.

The plausibility of unconfoundedness heavily relies on the quality and on the amount of the information contained in the vector $\boldsymbol{X}$. It is particularly important that such information includes the pre-treatment values of the outcome variables of interest, as these are likely to be good predictors of the outcomes themselves (Heckman et al., 1997).

For each generic pair of treatments $l$ and $m$, the main causal estimand of interest is the average treatment effect of $l$ for the subpopulation of firms receiving $l$ rather than $m$, known as average treatment effect on the treated (ATT). Under the assumption of strong ignorability, such ATT can be written as follows:

$A T T_{l, m}=E\left[Y_{i}(l)-Y_{i}(m) \mid T=l, X_{i}=x\right]$.

In our context of application, the way the causal estimands presented above may be interpreted depends on what types of treatments $l$ and $m$ are (Table 2). If, for example, $l=c$ and $m=u$, then [1] is the effect of the subsidy for a collaborative project relative to no subsidy for firms that participate in the collaborative programme. If $l=s$ and $m=u,[1]$ is the effect of the subsidy to an individual project relative to

\footnotetext{
${ }^{8}$ Firms that, prior to policy participation, collaborated with universities and other firms are $22 \%$ of those receiving subsidies to collaborative R\&D, and $9 \%$ of those receiving subsidies to individual R\&D.

${ }^{9}$ These pre-treatment differences between firms participating in the two programmes are confirmed by tests on the equality of proportions, where the null hypothesis of equality is always rejected. On the other hand, the $p$-value associated to the test on the equality of means of the pre-treatment amount of R\&D investment does not allow to reject the null hypothesis of equality. The detailed results of the previous tests are available upon request to the authors.
} 
no subsidy for firms that participate in the programme for individual $\mathrm{R}$ $\& \mathrm{D}$ projects. If, instead, $l=c$ and $m=s,[1]$ is the effect of the subsidy to a collaborative project relative to the subsidy to an individual project for firms that actually take the former. Finally, if $l=s$ and $m=c$, [1] is the effect of the subsidy to an individual project relative to the subsidy to collaborative projects for firms that actually take the former.

Under the assumption of strong ignorability and in the presence of multiple treatments, the previous causal effects can be semi-parametrically estimated by means of propensity-score matching (Lechner 2002a, 2002b). The propensity score is a univariate summary of the information contained in the vector of pre-treatment covariates. For each pair of treatments $l$ and $m$, the propensity score is defined as $e_{i}^{l, m}=\operatorname{Pr}\left(T_{i}=l \mid \boldsymbol{X}_{i}, \mathrm{~T}=l, m\right)$. This summary has two important properties (Rosenbaum and Rubin, 1983): (i) it is a balancing score, in the sense that it theoretically guarantees that observations with the same value of the propensity score have the same distribution of observable characteristics independently of the treatment; (ii) if treatment assignment is strongly ignorable given $\boldsymbol{X}_{\boldsymbol{i}}$, then it is also strongly ignorable given the propensity score. The two properties together make it possible to match firms from different treatment groups using this univariate summary instead of the original covariates. In order to facilitate the estimation of a propensity score that satisfies the previous property (i), Imai and Ratkovic (2014) have recently proposed a generalisedmethod-of-moments estimator of the propensity score where a single model determines both the conditional probability of treatment assignment and optimised covariate balancing weights. A key advantage of this methodology is that it mitigates the harm deriving from a potential misspecification of a parametric propensity score, because the coefficients of the propensity score model are estimated maximising the covariate balance. Therefore, we resort to this powerful covariate-balancing propensity score (CBPS) estimator in our study. The covariates we insert in the CBPS models, one for each pair of treatment groups, are all the background characteristics defined in Table 1. They include the pre-treatment values of all outcome variables (including the deflated value of R\&D investment), a categorical variable for the sector of the firm, a categorical variable for firm size, a dummy for the firm's legal form and a categorical variable for the province in which the firm is located. The coefficients of the propensity score models are reported in Table A1 in the Appendix. After having ascertained that the estimated CBPSs always guarantee that the overlap assumption is satisfied in practice, we evaluate to which extent they also imply a satisfactory covariate balance. Following Imbens and Rubin (2015) and the previous methodological field literature, we perform this assessment by looking at normalised mean differences before and after conditioning on the estimated propensity scores (Table A2 in the Appendix). Such conditioning may take place by using propensity-score-based balancing weights (Imai and Ratkovic, 2014). With respect to the unconditional contrast between the mean level of pre-treatment covariates in each pair of treatment groups, once we condition on the estimated CBPSs we have considerable improvements in covariate balance. This notwithstanding, small differences persist in some of the pre-treatment values of outcome variables. We choose to address these residual differences in the pre-treatment values of all outcomes using the bias-corrected matching estimator by Abadie and Imbens (2011) that combines nearest-neighbour matching (based, in our case, on the propensity score as distance metric) with a correction factor calculated using a regression model for the outcome variable in the group of matched controls. ${ }^{10,11}$

\footnotetext{
${ }^{10}$ After conditioning on the propensity score $e^{c s}=\operatorname{Pr}(\mathrm{T}=c \mid \mathrm{X}, \mathrm{T}=c, s)$, some unbalance persists between the proportion of PPLC in the group of firms for which $\mathrm{T}=c$ and the proportion of PPLC in the group of firms for which $\mathrm{T}=s$ (Table A2 in the Appendix). Therefore, when estimating the $A T T_{c, s}$, we also adjust for the residual difference in the legal form.

${ }^{11}$ When the outcome variable is binary, bias correction occurs through a linear probability model.
}

We match each treated firm only to its nearest-neighbour, allowing for the replacement of controls. Variability estimation occurs using the analytic asymptotic variance estimator by Abadie and Imbens (2006), which focuses on cases, like ours, where matching occurs with replacement and with a fixed number of matches.

To tackle the problem of non-response of some firms that took the subsidy to collaborative R\&D projects, we adopted an inverse probability weighting strategy (Wooldridge, 2007; Rotnitzky, 2009). ${ }^{12}$ Under the assumption that there are no unmeasured confounders for both treatment and loss to follows-up due to non-response, in the estimation of the $\mathrm{ATT}_{c u}$ and the $\mathrm{ATT}_{c s}$ we apply the nearest neighbour estimator to outcomes weighed by the inverse of the probability of response. In so doing, the contribution of each treated respondent is directly proportional to the "rarity" of information provided by the same respondent. Each control unit receives the weight of the treated firm to which it is matched.

Specifically, let $R_{i}$ be a binary indicator equal to 1 if firm $i$ responds to the survey. The weight for each treated respondent is constructed as follows:

$w_{i, T=c}=1 / \operatorname{Pr}\left(R_{i}=1 \mid \boldsymbol{X}_{\dot{i}} T_{i}=c\right)$,

where $\boldsymbol{X}_{i}$ contains the covariates that are available for all treated firms, be they respondent or not (sector, province, legal form, number of employees prior to the programme).The probability contained in the previous equation was estimated using a logit model.

\section{Results}

We present now our estimates of the average treatment effect on the treated defined in Section 5.

Let us start by comparing the outcomes achieved under each of the two policies with the outcomes the same firms would achieve in the counterfactual no-policy scenario (Table 2 , 3rd and 4th columns). Then, we move to the direct comparison of the two policies (Table 2, 5th and 6th columns).

The subsidies to collaborative R\&D projects were effective in stimulating persistent networking behaviour in the firms that received them (henceforth, we call these C-type firms), and in increasing their propensity to engage in unsubsidised R\&D activities later on, while the subsidies to individual $R \& D$ projects raised the amount of investment in R\&D in the recipient firms (henceforth, we call these S-type firms) in the unsubsidised follow-up period. In particular, after the end of the policies, the probability to collaborate with external partners of C-type firms is $14 \%$ higher than it would have been without the collaboration subsidy, and their probability to collaborate with universities is $21 \%$ higher. On the other hand, it seems that the subsidies for collaborative R\&D did not substantially raise their probability of networking with other firms over time. This is in line with the idea, suggested by the literature recalled in the second section, that networking with this latter type of partner is not unlikely to occur spontaneously, while networking with universities can be facilitated by public support. Besides increasing their willingness to engage in subsequent innovation-related interactions with research organisations, participation in the R\&D collaboration policy induced a change in firms' behaviour towards R\&D activities.

Indeed, the causal effect of the subsidy to collaborative projects on the probability of performing any unsubsidised, internal R\&D in the follow-up period is almost $18 \%$, whereas its effect on the amount of R\&

\footnotetext{
12 The premise for the adoption of this strategy is that non-response does not depend on the outcome variable (Little and Rubin, 2014). Indeed, we believe that the information collected through the questionnaire is not so sensitive as to push companies to not respond. On the other hand, we cannot rule out that the respondents' selection process is not completely random. Under these circumstances, it makes sense to assume that nonresponse occurs at random conditional on a vector of observable variables, including those used for estimating the propensity score.
} 
Table 2

Estimates of the $\mathrm{ATT}_{l m}$. Standard errors in parentheses, $p$-values in brackets.

\begin{tabular}{|c|c|c|c|c|}
\hline \multirow[t]{2}{*}{ Outcome variable } & \multicolumn{2}{|c|}{ Treatment vs no treatment } & \multicolumn{2}{|c|}{$\begin{array}{l}\text { Treatment } c \text { vs treatment } s \text { and } \\
\text { viceversa }\end{array}$} \\
\hline & $\begin{array}{l}l=c \\
m=u\end{array}$ & $l=s ; m=u$ & $l=c ; m=s$ & $l=s ; m=c$ \\
\hline \multirow[t]{3}{*}{$R \& D$} & $0.178^{* *}$ & -0.039 & $0.138 * *$ & -0.038 \\
\hline & $(0.070)$ & $(0.049)$ & $(0.056)$ & $(0.123)$ \\
\hline & {$[0.011]$} & {$[0.430]$} & {$[0.014]$} & {$[0.761]$} \\
\hline \multirow[t]{3}{*}{ R\&D investment } & 30.801 & $63.836^{* *}$ & -28.451 & 28.986 \\
\hline & (19.139) & $(32.000)$ & $(22.350)$ & $(33.242)$ \\
\hline & {$[0.108]$} & {$[0.046]$} & {$[0.203]$} & [0.383] \\
\hline \multirow[t]{3}{*}{ Collaborations } & $0.144 * *$ & 0.012 & -0.016 & $-0.305^{* *}$ \\
\hline & $(0.070)$ & $(0.050)$ & $(0.068)$ & $(0.180)$ \\
\hline & {$[0.041]$} & {$[0.812]$} & {$[0.812]$} & {$[0.090]$} \\
\hline \multirow[t]{3}{*}{ Universities } & $0.206^{* *}$ & 0.021 & -0.081 & $-0.350^{* *}$ \\
\hline & $(0.072)$ & $(0.047)$ & $(0.076)$ & $(0.176)$ \\
\hline & {$[0.004]$} & {$[0.657]$} & {$[0.282]$} & {$[0.046]$} \\
\hline \multirow[t]{3}{*}{ Other firms } & 0.053 & 0.006 & -0.002 & $-0.373^{* *}$ \\
\hline & $(0.063)$ & $(0.036)$ & $(0.052)$ & $(0.173)$ \\
\hline & {$[0.400]$} & {$[0.871]$} & {$[0.970]$} & {$[0.031]$} \\
\hline
\end{tabular}

Note to table: Statistical significance: ${ }^{*} p<0.10,{ }^{* *} p<0.05,{ }^{* * *} p<0.01$.

D investment is statistically insignificant. This suggests that the subsidy to collaborative R\&D may induce former non performers to continue to invest in R\&D also beyond the time horizon of the subsidised project, but also that such later investments are not necessarily high. Such an inducement effect was not found for firms receiving the subsidy to individual R\&D projects, the vast majority of which already performed some R\&D prior to programme participation. However, the latter subsidy was able to increase the amount of future R\&D investment by around 64 thousand euro annually.

To evaluate which policy is more effective, it would not be correct to compare directly the two ATTs commented so far, as the participants in the two policies are partially different. To this end, we must go a step further (Table 2, 5th and 6th columns, as explained in Section 4) and perform ceteris paribus comparisons between the two.

The causal effect of the subsidy to collaborative R\&D on its recipients was to increase by about $13 \%$ the probability of subsequently performing unsubsidised R\&D activities (5th column). However, no significant effect is found in the amount of R\&D investment or on networking behaviour of the C-type firms. On the contrary, if we look at S-type firms, we find that the probability of having subsequent relationships either with universities or with other firms decreased by about 30\% (35\% for universities and 37\% for other firms). On the other hand, S-type firms would not have experienced any significant change in $R \& D$ had they participated in the other policy.

Summarizing, we cannot univocally confirm neither hypothesis $\mathrm{H} 1$ nor hypothesis $\mathrm{H} 2$ without accounting for the type of firms that receive the two different types of R\&D subsidies. This is, in our view, the most interesting part of the story, which will be further discussed in the next Section.

Before advancing any interpretation, in what follows we briefly assess the risk that the previous findings are false positives. Indeed, when one performs multiple tests on the same data, some of these tests may appear statistically significant purely by chance. To address this issue, we take the approach by Benjamini and Hochberg (1995) based on false discovery rates (FDR). A FDR is the maximum proportion that one is willing to accept of apparently significant results (discoveries) being false positives.

The statistical significance of all our estimated treatment effects is preserved by setting the FDR at $25 \%$, which entails that, in general, it is unlikely that our discoveries are false positives. In particular, when we consider $l=s$ and $m=u$, a FDR of $25 \%$ is required to preserve the statistical significance (at 10\%) of the positive effects estimated with respect to $R \& D$ investment. When we consider $l=s$ and $m=c$, the statistical significance (at 5\%) of the positive effects estimated with respect to Collaborations and Other firms is preserved, provided that we accept that only $20 \%$ of these two discoveries are false positives, whereas a FDR of $15 \%$ is sufficient to preserve statistical significance (at 5\%) of the positive effect on Universities. In all the other cases, a FDR of $10 \%$ is sufficient to confirm the statistical significance of our findings. In particular, where $l=c$ and $m=u$, the statistical significance (at $1 \%$ ) of the positive treatment effects on Universities is already guaranteed by a FDR of $5 \%$, whereas significance (at $5 \%$ ) of positive effects on $R \& D$ and Collaborations requires the FDR to be set at $10 \%$. Finally, where $l=c$ and $m=s$, a FDR of $10 \%$ is enough to preserve the statistical significance (at 5\%) of the positive effect discovered with respect to $R \& D$.

\section{Do we need subsidies to collaborative $R \& D$ to stimulate $R \& D$ and networking? A brief discussion}

In this section, we elaborate on the results of the previous analysis, which suggest that subsidies for collaborative R\&D and subsidies for individual R\&D are used by partially different firms, and therefore their success depends on the type of firms they are able to attract. They also suggest that things do not always go as expected.

Our findings show that, in general, policies subsidising collaborative R\&D do not necessarily perform better than policies subsidising individual R\&D. It is true that the former policy stimulates the participating firms to embark in R\&D activities in an unsubsidised future, and that it does so more than the latter policy. However, the participants in the policy subsidising individual R\&D would not have increased their $\mathrm{R}$ \&D had they participated in the former. In addition, although the beneficiaries of subsidies to individual projects would have increased their networking had they taken the collaborative subsidy, the opposite is not true. Indeed, the point is that the participants in the two policies are partly different, although not enough to impede any ceteris paribus comparison.

The policy supporting collaborative R\&D attracts firms that are relatively more accustomed to networking than to internal R\&D effort, and induces them to confirm such collaborative effort, but a classical subsidy to individual projects would be sufficient to achieve the same goal. Evidently, the innovation model of these firms is based on collaborations with external organisations, and, no matter what type of funded project they participate in, they do search for external collaborations. If, instead, subsidies to collaborative R\&D were given to firms that are relatively more inclined towards an in-house innovation model and are not so accustomed to collaborate, then the collaboration subsidy would pave the way to future networking more than the subsidy to individual projects.

On the other hand, the subsidy to collaborative R\&D stimulates R\&D in firms that, prior to policy participation, were not accustomed to R\&D investment. This suggest that, for many of these firms, collaboration can be a gateway to internal R\&D, to the extent that they might need to collaborate with others in order to understand that own R\&D effort is also important in order to get the most from collaborations (Cassiman and Veugelers, 2006; Lokshin et al., 2008; Lin et al., 2012). It is possible that after having carried out some R\&D activities through external collaborations, the firms have accumulated some internal knowledge and decide that it is worth to start their own R\&D activities. It is also possible that some learning by interacting is at work here, so that the firms learn how to structure such internal activities from the partners they collaborate with.

Our results highlight the importance for policymakers to choose the appropriate intervention given the characteristics of the targeted SMEs. If the policymakers' aim was to expand in a non-transitory way the number of SMEs that perform R\&D - i.e. to induce an improvement in the spontaneous extensive margin over time - they could target firms with modest R\&D experience through an R\&D collaboration policy, rather than implement an individual R\&D subsidy which would likely 
attract firms that are already performing internal R\&D and will continue to do so also when the subsidy is no longer there. Obviously, targeting can be difficult to do in practice. However, innovation intermediaries (Howells, 2006; Russo et al., 2016) that - in some sectors, technologies or territories - map the characteristics of firms and their skills could provide support in this activity.

Instead, if the policymakers' aim was to increase the total amount of R\&D investment - i.e. to induce an improvement in the spontaneous intensive margin over time - they should target SMEs that are already $\mathrm{R}$ $\& D$ performers and are likely to be ready to increase their effort, and either type of programme could be fine. This suggests that SMEs that are already R\&D performers may benefit more from the relief of financing constraints, rather than from the interorganisational learning triggered by R\&D collaboration.

Finally, if the policymakers' aim was to increase networking by SMEs, the implementation of a R\&D collaboration programme is likely to bring some positive results irrespective of the type of beneficiary firms, whereas the subsidy to individual projects is not.

Clearly, to elaborate highly precise policy design suggestions, it would also be important to establish which is the intensity of policy support that stimulates further investment in different types of firms, including R\&D experienced or unexperienced ones (Peters et al., 2017), or large or small firms (Bia and Mattei, 2012). However, this task goes beyond the scope of our analysis.

The previous results may have some implications in terms of the innovation policy mix (Flanagan et al., 2011). Indeed, the recognition of the fact that some interventions have different effects on different firms, and that some policies may be more effective than others in stimulating a particular effect stresses the importance of maintaining a relatively varied policy mix.

\section{Conclusions}

Our study makes an original contribution to the debate on innovation policies and its effectiveness. By comparing two different types of $R$ $\& D$ policies that used the same instrument (a subsidy), but promoted different activities (in-house R\&D investments vs collaborative R\&D), we found that the policy supporting collaborative R\&D was able to stimulate a change in firms' behaviour both towards R\&D investment and networking, but these different effects were likely to occur in different groups of firms. SMEs that, prior to policy participation, were less likely to collaborate with external organisations were those that could see, in an unsubsidised future, their propensity to networking improved by the participation in a policy supporting collaborative R\&D. SMEs that, prior to policy participation, were less likely to perform internal $\mathrm{R}$ \&D activities were those that could see, in an unsubsidised future, their propensity to perform some R\&D improved by receiving a subsidy for collaborative R\&D, thus raising the proportion of R\&D-performing SMEs in the economy.

Our results come from the analysis of a relatively small regional case study. Therefore, they should be corroborated by further empirical research conducted in other locations or regarding similar programmes of larger size before the last word is written on the topic. However, we believe that our contribution can stimulate further debate on whether, and for whom, subsidies to collaborative R\&D are preferable to other, and maybe simpler, forms of public support to the innovative activity of SMEs.

Furthermore, while we think that this issue is particularly important for SMEs, we have to highlight that our considerations apply to this type of firms only. Therefore, as R\&D policies are also relevant outside this specific field, it might be interesting to analyse policies in which large firms are involved.

\section{Acknowledgements}

We thank Dr. Albino Caporale and his colleagues from Regione Toscana and Sviluppo Toscana for their support in collecting and sharing the information and the administrative data on the policies they have implemented. We also thank three anonymous referees for their very valuable suggestions. Remaining errors are our own.

This research did not receive any specific grant from funding agencies in the public, commercial, or not-for-profit sectors.

\section{Appendix A}

Table A1

Estimated coefficients of the CBPS models.

\begin{tabular}{|c|c|c|c|c|c|c|c|c|c|c|c|c|}
\hline \multirow[t]{2}{*}{ CBPS model for: } & \multicolumn{3}{|c|}{$e^{s u}=\operatorname{Pr}(\mathrm{T}=s \mid \mathbf{X}, \mathrm{T}=s, u)$} & \multicolumn{3}{|c|}{$e^{c u}=\operatorname{Pr}(\mathrm{T}=c \mid \mathbf{X}, \mathrm{T}=c, u)$} & \multicolumn{3}{|c|}{$e^{c s}=\operatorname{Pr}(\mathrm{T}=c \mid \mathbf{X}, \mathrm{T}=c, s)$} & \multicolumn{3}{|c|}{$e^{s c}=\operatorname{Pr}(\mathrm{T}=s \mid \mathbf{X}, \mathrm{T}=s, c)$} \\
\hline & Estimate & S.E. & $p$-value & Estimate & S.E. & $p$-value & Estimate & S.E. & $p$-value & Estimate & S.E. & $p$-value \\
\hline Intercept & -0.823 & 1.420 & 0.562 & -1.140 & 2.250 & 0.612 & $4.310^{\text {*k. }}$ & 2.110 & 0.041 & $-4.590^{* *}$ & 1.870 & 0.014 \\
\hline Universities-1 $_{(1 / 0)}$ & $0.489^{*}$ & 0.268 & 0.069 & $1.090^{*}$ & 0.603 & 0.071 & $0.994^{* * * *}$ & 0.268 & 0.000 & $-0.908^{* k+k * k}$ & 0.271 & 0.001 \\
\hline Other firms $_{-1}(1 / 0)$ & 0.008 & 0.205 & 0.969 & 0.162 & 0.364 & 0.657 & $1.570^{\text {***k }}$ & 0.322 & 0.000 & $-1.480^{\text {*k*k }}$ & 0.278 & 0.000 \\
\hline$R \& D_{-1}(1 / 0)$ & $1.760^{* * * *}$ & 0.196 & 0.000 & 0.144 & 0.239 & 0.546 & $-2.520^{* * * k}$ & 0.371 & 0.000 & $2.110^{* * * k}$ & 0.374 & 0.000 \\
\hline $\mathrm{R} \& \mathrm{D}$ investment -1 & 0.001 & 0.294 & 0.997 & 0.001 & 0.219 & 0.997 & 0.002 & 0.314 & 0.994 & -0.002 & 0.286 & 0.995 \\
\hline \multicolumn{13}{|l|}{ Sector (base: Food) } \\
\hline Marble & $-1.920^{\text {*w*k }}$ & 0.224 & 0.000 & $-1.090^{\text {*k*k }}$ & 0.377 & 0.004 & 0.166 & 0.364 & 0.649 & 0.503 & 0.327 & 0.124 \\
\hline Fashion & $-2.660^{* * * *}$ & 0.395 & 0.000 & -0.337 & 0.408 & 0.408 & -1.050 & 0.788 & 0.181 & 0.924 & 0.738 & 0.210 \\
\hline Chemicals & $-2.530^{* * * *}$ & 0.345 & 0.000 & -0.308 & 0.308 & 0.317 & 0.044 & 0.418 & 0.916 & 0.164 & 0.426 & 0.701 \\
\hline Mechanics & $-2.560^{\text {***k }}$ & 0.166 & 0.000 & $-0.895^{\text {** }}$ & 0.436 & 0.040 & -0.458 & 0.737 & 0.534 & 0.267 & 0.690 & 0.699 \\
\hline Electrical machinery & $-2.580^{* * * *}$ & 0.254 & 0.000 & -0.570 & 0.469 & 0.224 & -0.996 & 0.704 & 0.157 & $1.630^{\text {k*k }}$ & 0.687 & 0.018 \\
\hline Automotive & $-2.050^{\text {**** }}$ & 0.203 & 0.000 & $0.594^{\text {*** }}$ & 0.232 & 0.010 & $1.400^{\text {**** }}$ & 0.408 & 0.001 & $-1.510^{\text {k.k*k }}$ & 0.368 & 0.000 \\
\hline Furniture & $-2.470^{\text {**** }}$ & 0.363 & 0.000 & -0.391 & 0.278 & 0.160 & $1.010^{\text {*kt }}$ & 0.414 & 0.015 & $-0.965^{* *}$ & 0.393 & 0.014 \\
\hline Energy and utilities & $-0.488^{\text {***k }}$ & 0.140 & 0.000 & $-0.604^{\text {*** }}$ & 0.248 & 0.015 & $-1.410^{\text {*⿻*k }}$ & 0.261 & 0.000 & $1.120^{* * * k}$ & 0.240 & 0.000 \\
\hline Constructions & $-2.490^{\text {**** }}$ & 0.298 & 0.000 & 0.175 & 0.305 & 0.566 & $-1.680^{\text {***k }}$ & 0.444 & 0.000 & $1.910^{* * * k}$ & 0.393 & 0.000 \\
\hline Wholesale/retail trade & $-1.370^{* * *}$ & 0.193 & 0.000 & $-1.500^{\text {*k*** }}$ & 0.306 & 0.000 & $-1.650^{\text {***k}}$ & 0.315 & 0.000 & $1.850^{* k * k}$ & 0.264 & 0.000 \\
\hline ICT & $-2.740^{\text {***k }}$ & 0.136 & 0.000 & -0.738 & 0.474 & 0.120 & -0.035 & 0.697 & 0.960 & 0.216 & 0.645 & 0.738 \\
\hline R\&D services & $-3.150^{\text {*⿻*⿲丿丨丨巾 }}$ & 0.311 & 0.000 & $0.967^{* * *}$ & 0.386 & 0.012 & $-0.772^{* k *}$ & 0.328 & 0.019 & $-0.871^{k \ldots k * k}$ & 0.333 & 0.009 \\
\hline Business services & $-2.270^{\text {**** }}$ & 0.401 & 0.000 & $-1.060^{\text {*** }}$ & 0.489 & 0.031 & $-2.150^{\text {***k }}$ & 0.408 & 0.000 & $2.010^{\text {*k:k }}$ & 0.413 & 0.000 \\
\hline Other sectors & $-1.260^{\text {**** }}$ & 0.211 & 0.000 & -0.548 & 0.357 & 0.125 & 0.305 & 0.608 & 0.616 & 0.092 & 0.597 & 0.877 \\
\hline
\end{tabular}


Table A1 (continued)

\begin{tabular}{|c|c|c|c|c|c|c|c|c|c|c|c|c|}
\hline \multirow[t]{2}{*}{ CBPS model for: } & \multicolumn{3}{|c|}{$e^{s u}=\operatorname{Pr}(\mathrm{T}=s \mid \mathbf{X}, \mathrm{T}=s, u)$} & \multicolumn{3}{|c|}{$e^{c u}=\operatorname{Pr}(\mathrm{T}=c \mid \mathbf{X}, \mathrm{T}=c, u)$} & \multicolumn{3}{|c|}{$e^{c s}=\operatorname{Pr}(\mathrm{T}=c \mid \mathbf{X}, \mathrm{T}=c, s)$} & \multicolumn{3}{|c|}{$e^{s c}=\operatorname{Pr}(\mathrm{T}=s \mid \mathbf{X}, \mathrm{T}=s, c)$} \\
\hline & Estimate & S.E. & $p$-value & Estimate & S.E. & $p$-value & Estimate & S.E. & $p$-value & Estimate & S.E. & $p$-value \\
\hline \multicolumn{13}{|c|}{$\begin{array}{l}\text { Employees }_{-1} \text { (base: Up to } \\
\text { 9) }\end{array}$} \\
\hline 10-29 employees & $0.849^{* * * *}$ & 0.307 & 0.006 & -0.243 & 0.209 & 0.245 & $-0.757^{\text {*k* }}$ & 0.363 & 0.037 & $0.819^{k * *}$ & 0.407 & 0.044 \\
\hline 30-49 employees & $1.480^{* * * *}$ & 0.291 & 0.000 & $-1.330^{\text {**** }}$ & 0.252 & 0.000 & $-2.010^{* * * *}$ & 0.321 & 0.000 & $1.630^{\text {*k*k }}$ & 0.327 & 0.000 \\
\hline $50+$ employees & 0.303 & 0.480 & 0.528 & -0.282 & 0.300 & 0.348 & -0.285 & 0.256 & 0.265 & -0.198 & 0.245 & 0.418 \\
\hline PPLC (1/0) & -0.296 & 0.194 & 0.127 & $1.360^{* * * *}$ & 0.221 & 0.000 & $-3.230^{* * * *}$ & 0.255 & 0.000 & $3.340^{* * * *}$ & 0.281 & 0.000 \\
\hline \multicolumn{13}{|c|}{$\begin{array}{l}\text { Province (base: Massa } \\
\text { Carrara) }\end{array}$} \\
\hline Lucca & -0.674 & 0.536 & 0.209 & $-1.240^{\text {***k }}$ & 0.293 & 0.000 & -0.071 & 0.330 & 0.831 & -0.560 & 0.330 & 0.090 \\
\hline Pistoia & 0.018 & 0.604 & 0.976 & $-1.650^{\text {**k* }}$ & 0.344 & 0.000 & $-2.750^{k * * *}$ & 0.291 & 0.000 & $3.230^{* * * k}$ & 0.288 & 0.000 \\
\hline Firenze & 0.115 & 0.431 & 0.790 & -0.835 & 0.508 & 0.100 & 0.133 & 0.462 & 0.773 & 0.225 & 0.401 & 0.575 \\
\hline Livorno & $-0.879^{* * *}$ & 0.405 & 0.030 & $-1.060^{\text {**** }}$ & 0.360 & 0.003 & $2.770^{k * * k}$ & 0.329 & 0.000 & $-2.350^{* * * *}$ & 0.307 & 0.000 \\
\hline Pisa & -0.471 & 0.418 & 0.260 & $-1.530^{* * * *}$ & 0.535 & 0.004 & -0.711 & 0.451 & 0.115 & $0.868^{k *}$ & 0.436 & 0.046 \\
\hline Arezzo & $-1.160^{* * *}$ & 0.547 & 0.034 & $-1.750^{* * * *}$ & 0.419 & 0.000 & $-2.240^{* * * *}$ & 0.293 & 0.000 & $2.660^{* * * k}$ & 0.276 & 0.000 \\
\hline Siena & -0.896 & 0.596 & 0.133 & -0.577 & 0.424 & 0.173 & $1.030^{* * * *}$ & 0.354 & 0.004 & $-0.806^{\text {*** }}$ & 0.338 & 0.017 \\
\hline Grosseto & $-2.020^{* * * k}$ & 0.215 & 0.000 & -0.574 & 0.434 & 0.186 & 0.321 & 0.281 & 0.254 & 0.098 & 0.279 & 0.727 \\
\hline Prato & 0.121 & 0.788 & 0.877 & 0.483 & 0.348 & 0.166 & 0.321 & 0.427 & 0.452 & 0.354 & 0.362 & 0.328 \\
\hline
\end{tabular}

Note to table: Statistical significance: ${ }^{*} p<0.10,{ }^{* * *} p<0.05,{ }^{* * * *} p<0.01$.

Table A2

Normalised mean differences in the covariates of alternative treatment groups, unconditional and conditional on the estimated CBPS.

\begin{tabular}{|c|c|c|c|c|c|c|c|c|}
\hline & \multicolumn{2}{|c|}{$e^{s u}=\operatorname{Pr}(\mathrm{T}=s \mid \mathbf{X}, \mathrm{T}=\mathrm{s}, u)$} & \multicolumn{2}{|c|}{$e^{c u}=\operatorname{Pr}(\mathrm{T}=c \mid \mathbf{X}, \mathrm{T}=c, u)$} & \multicolumn{2}{|c|}{$e^{c s}=\operatorname{Pr}(\mathrm{T}=c \mid \mathbf{X}, \mathrm{T}=c, s)$} & \multicolumn{2}{|c|}{$e^{s c}=\operatorname{Pr}(\mathrm{T}=s \mid \mathbf{X}, \mathrm{T}=s, c)$} \\
\hline & $\begin{array}{l}\text { Unconditional on } \\
e^{s u}\end{array}$ & $\begin{array}{l}\text { Conditional on } \\
e^{s u}\end{array}$ & $\begin{array}{l}\text { Unconditional on } \\
e^{c u}\end{array}$ & $\begin{array}{l}\text { Conditional on } \\
e^{c u}\end{array}$ & $\begin{array}{l}\text { Unconditional on } \\
e^{c s}\end{array}$ & $\begin{array}{l}\text { Conditional on } \\
e^{c s}\end{array}$ & $\begin{array}{l}\text { Unconditional on } \\
e^{s c}\end{array}$ & $\begin{array}{l}\text { Conditional on } \\
e^{s c}\end{array}$ \\
\hline $\begin{array}{l}\text { Universities }_{-1}(1 / \\
0)\end{array}$ & 0.370 & 0.001 & 0.570 & 0.129 & 0.413 & 0.070 & -0.413 & -0.126 \\
\hline $\begin{array}{l}\text { Other firms } \text { f }_{-1}(1 / \\
0)\end{array}$ & 0.258 & 0.012 & 0.174 & 0.018 & 0.451 & 0.041 & -0.451 & -0.120 \\
\hline $\mathrm{R} \& \mathrm{D}_{-1}(1 / 0)$ & 0.807 & 0.010 & 0.464 & 0.062 & -0.577 & -0.314 & 0.577 & 0.126 \\
\hline R\&D investment -1 & 0.744 & 0.086 & 0.415 & 0.175 & -0.062 & -0.120 & 0.062 & -0.174 \\
\hline Food & 0.097 & 0.022 & 0.055 & -0.005 & 0.273 & 0.151 & -0.273 & 0.026 \\
\hline Marble & 0.010 & -0.006 & -0.114 & -0.012 & 0.122 & -0.086 & -0.122 & 0.018 \\
\hline Fashion & 0.057 & -0.008 & 0.044 & 0.017 & -0.490 & -0.065 & 0.490 & 0.379 \\
\hline Chemicals & 0.039 & -0.003 & 0.070 & 0.016 & 0.054 & 0.133 & -0.054 & 0.073 \\
\hline Mechanics & -0.133 & -0.007 & -0.002 & -0.021 & -0.059 & -0.193 & 0.059 & -0.410 \\
\hline $\begin{array}{l}\text { Electrical } \\
\text { machinery }\end{array}$ & 0.053 & 0.011 & 0.060 & 0.000 & -0.016 & -0.038 & 0.016 & -0.048 \\
\hline Automotive & -0.012 & -0.003 & 0.283 & 0.151 & 0.174 & -0.005 & -0.174 & -0.170 \\
\hline Furniture & -0.032 & -0.003 & -0.122 & -0.008 & -0.066 & 0.047 & 0.066 & 0.064 \\
\hline $\begin{array}{r}\text { Energy and } \\
\text { utilities }\end{array}$ & 0.131 & 0.148 & 0.019 & -0.013 & 0.060 & 0.079 & -0.060 & 0.049 \\
\hline Constructions & 0.091 & 0.013 & 0.105 & -0.015 & 0.235 & 0.206 & -0.235 & 0.020 \\
\hline $\begin{array}{l}\text { Wholesale/retail } \\
\text { trade }\end{array}$ & -0.030 & 0.000 & -0.192 & -0.006 & -0.073 & -0.079 & 0.073 & -0.061 \\
\hline ICT & -0.105 & 0.000 & -0.020 & -0.016 & 0.239 & -0.013 & -0.239 & -0.082 \\
\hline R\&D services & -0.051 & 0.001 & 0.234 & -0.004 & 0.244 & 0.044 & -0.244 & -0.016 \\
\hline Business services & -0.032 & -0.003 & -0.144 & -0.001 & 0.183 & 0.121 & -0.183 & -0.160 \\
\hline Other sectors & 0.126 & -0.020 & 0.010 & -0.026 & -0.097 & -0.011 & 0.097 & 0.171 \\
\hline Up to 9 employees & -0.545 & -0.007 & 0.024 & 0.020 & 0.699 & 0.342 & -0.699 & -0.170 \\
\hline 10-29 employees & 0.044 & 0.004 & 0.013 & -0.011 & -0.184 & -0.230 & 0.184 & 0.039 \\
\hline 30-49 employees & 0.434 & -0.011 & -0.181 & -0.031 & -0.596 & -0.149 & 0.596 & 0.133 \\
\hline $50+$ employees & 0.185 & 0.028 & 0.180 & 0.024 & 0.177 & 0.051 & -0.177 & -0.042 \\
\hline PPLC $(1 / 0)$ & -0.035 & -0.005 & 0.694 & 0.063 & -0.932 & -0.828 & 0.932 & 0.024 \\
\hline Massa Carrara & 0.019 & 0.045 & 0.135 & -0.004 & 0.227 & 0.095 & -0.227 & -0.053 \\
\hline Lucca & -0.046 & 0.000 & -0.122 & -0.009 & -0.099 & -0.066 & 0.099 & -0.193 \\
\hline Pistoia & 0.083 & -0.004 & -0.072 & -0.007 & -0.270 & -0.085 & 0.270 & 0.192 \\
\hline Firenze & 0.152 & -0.005 & -0.024 & -0.031 & -0.172 & -0.068 & 0.172 & -0.087 \\
\hline Livorno & -0.099 & -0.001 & 0.024 & 0.061 & 0.415 & 0.285 & -0.415 & -0.028 \\
\hline Pisa & -0.034 & 0.007 & -0.217 & -0.015 & -0.048 & -0.261 & 0.048 & 0.042 \\
\hline Arezzo & -0.181 & -0.004 & -0.143 & 0.005 & -0.137 & -0.116 & 0.137 & -0.225 \\
\hline Siena & -0.153 & -0.002 & 0.049 & -0.005 & 0.338 & 0.232 & -0.338 & -0.008 \\
\hline Grosseto & -0.062 & -0.003 & 0.125 & -0.012 & 0.308 & 0.280 & -0.308 & 0.018 \\
\hline Prato & 0.118 & -0.011 & 0.280 & 0.031 & -0.128 & -0.022 & 0.128 & 0.203 \\
\hline
\end{tabular}




\section{References}

Abadie, A., Imbens, G.W., 2006. Large sample properties of matching estimators for average treatment effects. Econometrica 74, 235-267.

Abadie, A., Imbens, G.W., 2011. Bias-corrected matching estimators for average treatment effects. J. Bus. Econ. Stat. 29, 1-11.

Antonioli, D., Marzucchi, A., Montresor, S., 2014. Regional innovation policy and innovative behaviour: looking for additional effects. Eur. Plann. Stud. 22, 64-83.

Arqué-Castells, P., Mohnen, P., 2015. Sunk costs, extensive R\&D subsidies and permanent inducement effects. J. Ind. Econ. 63, 458-494.

Arundel, A., Geuna, A., 2004. Proximity and the use of public science by Innovative European Firms. Econ. Innov. New Technol. 13, 559-580.

Autio, E., Kanninen, S., Gustafsson, R., 2008. First- and second-order additionality and learning outcomes in collaborative R\&D programs. Res. Policy 37, 59-76.

Baldwin, C.Y., Clark, K.B., 2000. Design Rules: The Power of Modularity. MIT Press, Boston.

Barnes, T., Pashby, I., Gibbons, A., 2002. Effective university-industry interaction: a multi-case evaluation of collaborative R\&D projects. Eur. Manage. J. 20, 272-285.

Benjamini, Y., Hochberg, Y., 1995. Controlling the false discovery rate: a practical and powerful approach to multiple testing. J. R. Stat. Soc. Ser. B 57, 289-300.

Bia, M., Mattei, A., 2012. Assessing the effect of the amount of financial aids to Piedmont firms using the generalized propensity score. Stat. Methods Appl. 21, 485-516.

Blanes, J.V., Busom, I., 2004. Who participates in R\&D subsidy programs?: The case of Spanish manufacturing firms. Res. Policy 33, 1459-1476.

Bloom, N., Van Reenen, J., 2010. New approaches to surveying organizations. Am. Econ. Rev. 100, 105-109.

Bocci, C., Mariani, M., 2015. L'approccio delle funzioni dose-risposta per la valutazione di trattamenti continui nei sussidi alla R\&S. Scienze Regionali 14 (3), 81-102.

Bruneel, J., D'Este, P., Salter, A., 2010. Investigating the factors that diminish the barriers to university-industry collaboration. Res. Policy 39 , 858-868.

Buisseret, T.J., Cameron, H.M., Georghiou, L., 1995. What difference does it make? Additionality in the public support of R\&D in large firms. Int. J. Technol. Manage. 10, $587-600$.

Busom, I., Fernández-Ribas, A., 2008. The impact of firm participation in R\&D programmes on R\&D partnerships. Res. Policy 37 (2), 240-257.

Busom, I., Corchuelo, B., Martínez-Ros, E., 2014. Tax incentives... or subsidies for business R\&D? Small Bus. Econ. 43, 571-596.

Caloffi, A., Mariani, M., 2018. Regional policy mixes for enterprise and innovation: a fuzzy-set clustering approach. Environ. Plann. C: Polit. Space 36, 28-46.

Caloffi, A., Rossi, F., Russo, M., 2017. A Tale of Persistent Network Additionality, with Evidence from a Regional Policy. Working Paper CIMR. Centre for Innovation Management Research (n.38).

Carlsson, B., Jacobsson, S., 1997. In search of useful public policies-key lessons and issues for policy makers. In: Carlsson, B. (Ed.), Technological Systems and Industrial Dynamics. Springer, London, pp. 299-315.

Cassiman, B., Veugelers, R., 2006. In search of complementarity in innovation strategy: internal R\&D and external knowledge acquisition. Manage. Sci. 52, 68-82.

Chesbrough, H., Vanhaverbeke, W., West, J., 2006. Open Innovation: Researching a New Paradigm. Oxford University Press, Oxford.

Clarysse, B., Wright, M., Mustar, P., 2009. Behavioural additionality of R\&D subsidies: a learning perspective. Res. Policy 38, 1517-1533.

Cohen, W.M., Levinthal, D.A., 1989. Innovation and learning: the two faces of R\&D. Econ. J. 99 (397), 569-596.

Cooke, P., Uranga, M.G., Etxebarria, G., 1997. Regional innovation systems: institutional and organisational dimensions. Res. Policy 26, 475-491.

Cyert, R.M., March, J.G., 1963. A Behavioral Theory of the Firm. Prentice Hall, Englewood Cliffs, NJ.

David, P.A., Hall, B.H., 2000. Heart of darkness: modeling public-private funding interactions inside the R\&D black box. Res. Policy 29, 1165-1183.

Dodgson, M., 1992. The strategic management of R\&D collaboration. Technol. Anal. Strateg. Manage. 4, 227-244.

Dodgson, M., 1993. Learning, trust, and technological collaboration. Hum. Relat. 46, 77-95.

Dyer, J.H., Singh, H., 1998. The relational view: cooperative strategy and sources of interorganizational competitive advantage. Acad. Manage. Rev. 23, 660-679.

Falk, R., 2007. Measuring the effects of public support schemes on firms' innovation activities: survey evidence from Austria. Res. Policy 36, 665-679.

Flanagan, K., Uyarra, E., Laranja, M., 2011. Reconceptualising the 'policy mix' for innovation. Res. Policy 40, 702-713.

Fontana, R., Geuna, A., Matt, M., 2006. Factors affecting university-industry R\&D projects: the importance of searching, screening and signalling. Res. Policy 35, 309-323.

Garza, D., Giat, Y., Hackman, S.T., Peled, D., 2015. A computational analysis of R\&D support programs. Econ. Innov. New Technol. 24, 682-709.

Georghiou, L., Clarysse, B., 2006. Introduction and synthesis. In: OECD (Ed.), Government R\&D Funding and Company Behaviour, Measuring Behavioural Additionality. OECD, Paris, pp. 9-38.

González, X., Jaumandreu, J., Pazó, X., 2005. Barriers to innovation and subsidy effectiveness. Rand J. Econ. 36, 930-950.

Hægeland, T., Møen, J., 2007. The Relationship between the Norwegian R\&D Tax Credit Scheme and Other Innovation Policy Instruments. Report 2007/45. Statistics Norway, Oslo.

Hagedoorn, J., Link, A.N., Vonortas, N.S., 2000. Research partnerships. Res. Policy 29, $567-586$.

Heckman, J.J., Ichimura, H., Todd, P.E., 1997. Matching as an econometric evaluation estimator: evidence from evaluating a job training programme. Rev. Econ. Stud. 64 605-654.

Hekkert, M.P., Negro, S.O., 2009. Functions of innovation systems as a framework to understand sustainable technological change: empirical evidence for earlier claims. Technol. Forecast. Soc. Change 76, 584-594.

Hollanders, H., Es-Sadki, N., 2017. Regional Innovation Scoreboard 2017. European Commission, Bruxelles.

Howells, J., 1996. Tacit knowledge. Technol. Anal. Strateg. Manage. 8, 91-106.

Howells, J., 2006. Intermediation and the role of intermediaries in innovation. Res. Policy 35, 715-728.

Huergo, E., Moreno, L., 2017. Subsidies or loans? Evaluating the impact of R\&D support programmes. Res. Policy 46, 1198-1214.

Imai, K., Ratkovic, M., 2014. Covariate balancing propensity score. J. R. Stat. Soc.: Ser. B 76 (1), 243-263.

Imbens, G.W., Rubin, D.B., 2015. Causal Inference in Statistics, Social, and Biomedical Sciences. Cambridge University Press, Cambridge.

Kale, P., Singh, H., Perlmutter, H., 2000. Learning and protection of proprietary assets in strategic alliances: building relational capital. Strateg. Manage. J. 21, 217-237.

Kleinknecht, A., Reijnen, J.O., 1991. More evidence on the undercounting of small firm R \&D. Res. Policy 20, 579-587.

Klette, T.J., Møen, J., 2012. R\&D investment responses to R\&D subsidies: a theoretical analysis and a microeconometric study. World Review of Science. Technol. Sustain. Dev. 9, 169-203.

Laursen, K., Salter, A., 2004. Searching low and high: what types of firms use universities as a source of innovation? Res. Policy 33, 1201-1215.

Laursen, K., Salter, A., 2006. Open for innovation: the role of openness in explaining innovative performance among UK manufacturing firms. Strateg. Manage. J. 27, 131-150.

Lechner, M., 2002a. Program heterogeneity and propensity score matching: an application to the evaluation of active labor market policies. Rev. Econ. Stat. 84, 205-220.

Lechner, M., 2002b. Some practical issues in the evaluation of heterogeneous labour market programmes by matching methods. J. R. Stat. Soc.: Ser. A 165, 59-82.

Lee, S., Park, G., Yoon, B., Park, J., 2010. Open innovation in SMEs-an intermediated network model. Res. Policy 39, 290-300.

Lin, C., Wu, Y.J., Chang, C., Wang, W., Lee, C.Y., 2012. The alliance innovation performance of R\&D alliances - the absorptive capacity perspective. Technovation 32, 282-292.

Little, R.J., Rubin, D.B., 2014. Statistical Analysis with Missing Data. John Wiley \& Sons, London.

Lockett, A., Wright, M., 2005. Resources, capabilities, risk capital and the creation of university spin-out companies. Res. Policy 34, 1043-1057.

Lokshin, B., Belderbos, R., Carree, M., 2008. The productivity effects of internal and external R\&D: Evidence from a dynamic panel data model. Oxford Bull. Econ. Stat. 70, 399-413.

Marzucchi, A., Montresor, S., 2015. The multi-dimensional additionality of innovation policies. A multi-level application to Italy and Spain. In: Crespi, F., Quatraro, F. (Eds.), The Economics of Knowledge, Innovation and Systemic Technology Policy. Routledge, London.

Metcalfe, S., Georghiou, L., 1997. Equilibrium and Evolutionary Foundations of Technology Policy. (CRIC Discussion Paper No 3).

Mohnen, P., Hoareau, C., 2003. What type of enterprise forges close links with universities and government labs? Evidence from CIS 2. Manage. Decis. Econ. 24, 133-145.

Narula, R., 2004. R\&D collaboration by SMEs: new opportunities and limitations in the face of globalisation. Technovation 24, 153-161.

Nooteboom, B., 1994. Innovation and diffusion in small firms: theory and evidence. Small Bus. Econ. 6, 327-347.

Ortega-Argilés, R., Vivarelli, M., Voigt, P., 2009. R\&D in SMEs: a paradox? Small Bus. Econ. 33, 3-11.

Peneder, M., 2008. The problem of private under-investment in innovation: A policy mind map. Technovation 28, 518-530.

Peters, B., Roberts, M.J., Vuong, V.A., Fryges, H., 2017. Estimating dynamic R\&D choice: an analysis of costs and long-run benefits. Rand J. Econ. 48, 409-437.

Petruzzelli, A.M., Rotolo, D., 2015. Institutional diversity, internal search behaviour, and joint-innovations. Manage. Decis. 53, 2088-2106.

Polanyi, M., 1966. The Tacit Dimension. The University of Chicago, Chicago.

Powell, W.W., 1996. Inter-organizational collaboration in the biotechnology industry. J. Inst. Theor. Econ. 152 (1), 197-215.

Rahm, D., Kirkland, J., Bozeman, B., 2000. University-Industry R\&D Collaboration in the United States, the United Kingdom, and Japan. Springer, Dordrecht.

Rammer, C., Czarnitzki, D., Spielkamp, A., 2009. Innovation success of non-R\&D-performers: substituting technology by management in SMEs. Small Bus. Econ. 33, 35-58.

Roper, S., Hewitt-Dundas, N., 2014. The legacy of public subsidies for innovation: input, output and behavioural additionality effects. Enterprise Research Centre Research Paper, n.21.

Rosenbaum, P.R., Rubin, D.B., 1983. The central role of the propensity score in observational studies for causal effects. Biometrika 70, 41-55.

Rosenbaum, P.R., Rubin, D.B., 1985. Constructing a control group using multivariate matched sampling methods that incorporate the propensity score. Am. Stat. 39, 33-38.

Rotnitzky, A., 2009. Inverse probability weighted methods. In: Fitzmaurice, G., Davidian, M., Verbeke, G., Molenberghs, G. (Eds.), Longitudinal Data Analysis. CRC Press, London, pp. 453-476.

Russo, M., Rossi, F., 2009. Cooperation networks and innovation: a complex systems 
perspective to the analysis and evaluation of a regional innovation policy programme. Evaluation 15, 75-99.

Russo, M., Caloffi, A., Rossi, F., Righi, R., 2016. Designing performance-based incentives for innovation intermediaries: evidence from regional innovation poles. Working Paper CIMR - Centre for Innovation Management Research n.34.

Sauermann, H., Stephan, P., 2013. Conflicting logics? A multidimensional view of industrial and academic science. Organ. Sci. 24, 889-909.

Som, O., 2012. Innovation Without R\&D: Heterogeneous Innovation Patterns of Non-R\& D-Performing Firms in the German Manufacturing Industry. Springer Verlag, Wiesbaden.

Teirlinck, P., Spithoven, A., 2013. Research collaboration and R\&D outsourcing: different
R\&D personnel requirements in SMEs. Technovation 33, 142-153.

Van Gils, A., Zwart, P., 2004. Knowledge acquisition and learning in dutch and belgian SMEs: the role of strategic alliances. Eur. Manage. J. 22, 685-692.

Van de Vrande, V., de Jong, J., Vanhaverbeke, W., De Rochemont, M., 2009. Open in novation in SMEs: trends, motives and management challenges. Technovation 29 , 423-437.

Vossen, R.W., 1998. Research note-relative strengths and weaknesses of small firms in innovation. Int. Small Bus. J. 16, 88-94.

Wooldridge, J.M., 2007. Inverse probability weighted estimation for general missing data problems. J. Econometr. 141 (2), 1281-1301. 